\title{
COMPARISON AS MEANS OF EVALUATION \\ IN BANNER ADVERTISING
}

\author{
T. Krutko ${ }^{1}$
}

DOI: http://doi.org/10.15350/L_27/04

\begin{abstract}
Comparison is one of the effective means of evaluation in virtual advertising. It is proved that comparative constructions are widely used in the English, Russian, and Ukrainian banner ads. Clausal comparisons as well as combination of superlative and comparative degree can be found in the English banner ads. Phrasal comparisons with a null comparative are typical for the Russian and Ukrainian banner ads.
\end{abstract}

Keywords: banner ads, comparison, advertising discourse.

В рекламном дискурсе оценка является имманентной величиной, адекватную реализацию которой обеспечивают разцичные языковые средства. Ученые насчитывают около десяти показатецей оценности, среди которых мексико-семантические, грамматические, словообразовательные, стилистические и т.д. [2]. Категория оценки, реализованная различными языковыми средствами, является семантическим ядром рекламных текстов, в том числе текстов виртуальной рекламы.

Виртуальная реклама как динамично развивающийся и перспективный тип рекламной коммуникации, характеризующийся визуальными, структурными, содержательными особенностями, уже почти десятиметие привлекает внимание мингвистов. Осуществляется мингвосемиотический анализ текстов баннерной рекламы (Т.В. Крутько), изучаются их когнитивнопрагматические особенности (Е.С. Иванова), коммуникативные стратегии (А.Д. Белова).

Небольшая площадь рекламного баннера и короткое время его воздействия на адресата заставцяют адресанта создавать

${ }^{1}$ Tetiana Krutko, Candidate of Philological Sciences, Associate Professor, National University of Water and Environmental Engineering, Ukraine. 
многоуровневый рекламный текст, в котором простые для когнитивной обработки элементы разных уровней языка, в сочетании с невербальными компонентами, призваны убедить адресата рекмамы в необходимости осуществ ения запрограммированных рекламистами действий, а именно в необходимости активизации баннера [1, с. 184].

Kaк явмение многогранное и постоянно развивающееся

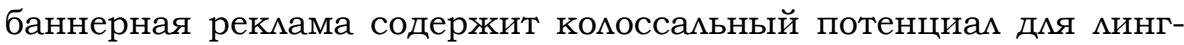
вистических исследований, в частности изучения грамматических способов выражения оценки на материале английского, русского, украинского языков.

В текстах баннерной рекламы грамматические способы выражения оценки, в частности компаративные конструкции, которые активизируют механизм сравнения, явцяются средством формирования и интенсификации воздействующего потенциала рекламного текста.

Функцией компаратива как непосредственного выразителя категории компаративности является обозначение относительной разницы между сравниваемыми предметами или рядами предметов (имплицированными ими эксплицированными) в соответствии со степенью обладания присущим им качеством: Sometimes BIGGER is BETTER; Кавова гуша ерективніша за дорогу космети$\kappa y$.

Используя компаративы, создатели рекламы актуализируют значимые признаки предмета рекламирования, которые домжны отмичать его от других объектов того же вида: Introducing Super Pixel Fonts! Now smoother and cleaner, sell your stuff faster on Yahoo! Classifieds; Nisan Tiida docmynнiше на 4750 у.е.; Копни глубже www.ukrrudprom.com

Текстам баннерной рекламы, относящимся к текстам малой формы, свойственны чрезмерная маконичность, емкость, содержательность текстового наполнения, компрессия. Среди синтаксических форм, характеризующихся этими качествами, особое место занимают неполные сравнительные конструкции с имплицитным эталоном сравнения, которые широко используются в текстах англо-, русско-, украиноязычной рекламы. Атрибутивные компаративы в неполных сравнительных конструкциях помогают подчеркнуть преимущества предмета рекламирования: Now there's an easier faster more accurate way to analyze Web site traffic; Want a better way to search Austin and the web? Click here; Бydb 
выше! VIP объявление; Vепи Більш комфортне гоління.

Среди сравнительных конструкций с эксплицитным эталоном сравнения в англоязычных рекламных текстах фиксируются единицы, где первая часть является предикативной, а вторая непредикативной: He makes more money than you. He gets better jobs than you. He earns more respect than you. He is more in demand than you. You can't beat him unless you join him. Click here for FREE certification tests. Brainbech the measure of achievement; конструкции с двумя непредикативными частями: Visa Smarter than your average card.

Анализ ангмоязычного эмпирического корпуса свидетельствует об обращении копирайтеров к компаративным конструкциям с маркерами сравнения like: Your interest rate shouldn't be like a BLIND DATE; as: Web Authoring Software that is easy as pie; It's easy as 123; Easy as DELL; than: Faster than a speeding bullet. Smarter than a locomotive.

В рекламных текстах, адресованных русскоязычной и украиноязычной аудитории, использование полных сравнительных конструкций с эксплицитным эталоном сравнения является не столь распространенным, как в англоязычной рекламе: Волосы как шелк. Новинка Gliss Kur "Жидкий шелк".

С целью выражения наивысшей оценки в текстах баннерной рекламы копирайтеры используют суперлатив как одно из популярнейших средств объективации максимальной степени проявцения признака: the web's most popular shoe store!; Japan's most explosive director has you in his sights; Expose your listing to the Internet's largest audience; Самый семейный сайm www.7ya.ru; Самая крупная конферениия в Уанете; Найкраші протизламні двері виготовляють в Рівному www.stal-m.иа; board.club.co.ua безкоштовна дошка оголошень: найшвидший спосіб продати, купити, обміняти; Сота Экономь время выбери лучшее!; Самая спортивная новость Чемпионат.ру.

В текстах англоязычной рекламы фиксируется сочетание суперлатива и компаратива, что позволяет рекламистам достигать максимальной интенсификации выражения оценки в рекламном сообщении: Earth's biggest selection just got bigger; The coolest version of Photoshop just got cooler.

В рекламном тексте Low 3.9\% Intro APR Lower 2.9\% Intro APR Lowest O\% Intro APR. Yahoo!Platinum Visa Card дмя демонстрации преимуществ кредитной карточки Visa копирайтеры использова- 
ми компаративно-суперлативную конструкцию в сочетании с синтаксическим параллелизмом, что способствует прогнозируемости рекцамного текста и, соответственно, облегчает его восприятие и запоминаемость.

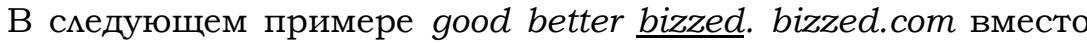
прогнозируемого прилагательного в превосходной степени сравнения best использован адрес рекламируемого веб-сайта. Такой прием позволяет копирайтерам создать эффект обманутого ожидания, когда в высказывании появляется элемент малой вероятности, нарушающий непрерывность сообщения и создающий неожиданность, которые вызывают сопротивцение восприятия, требуют усимия со стороны читателя, а потому симьнее на него воздействуют (И. В. Арнольд). Эффект обманутого ожидания позволяет акцентировать внимание на наиболее значимых компонентах рекцамного сообщения, в данном случае - на адресе вебсайта.

Использование образного сравнения - стилистического приема, основанного на сопоставцении - явцяется средством эмоциональной интенсификации рекламного сообщения: Paradise Falls may look like heaven...; Your faith is like a muscle.

Категория оценки, реализованная при помощи грамматической категории сравнения, выступает средством формирования и интенсификации воздействующего потенциала рекламного текста. Как средство эмоционально-оценочного влияния сравнительные конструкции позволяют рекламистам формировать положительный образ рекламируемого объекта, подчеркивать его исключительность.

Сравнительные конструкции являются прессупозициональным компоненом рекламного текста, то есть вводят информацию, претендующую на статус не требующего доказательств объективного факта, и, соответственно, являются приемом языкового манипулирования. Так, в рекламных текстах Самый удобный сайт объявлений Obyava.ua.net; the web's most popular shoe store! сравнительные конструкции используются с целью усиления директивной имлокуции, убеждения адресата в уникамьности рекламируемых объектов, являются рекомендацией к посещению сайтов и, кроме того, способствуют маконизации рекламных текстов.

Таким образом, сравнительные конструкции, широко используемые в текстах англоязычной, русскоязычной и украиноязычной баннерной рекламы, явцяются средством реализации 
прагматической установки рекламного текста, а именно формирования положительной оценки объекта рекламирования. Среди англоязычных рекламных текстов фиксируются как полные сравнительные конструкции с эксплицитным эталоном сравнения, так и неполные конструкции с имплицитным эталоном сравнения. Для текстов баннерной рекламы на русском и украинском языках характерно использование неполных сравнительных конструкций с имплицитным эталоном сравнения.

References:

[1] Крутько Т.В. Эргономические характеристики виртуальной рекмамы / Т.В. Крутько // Язык - когниция - социум: тезисы докл. Междунар. науч. конф., Минск, 12-13 ноября 2012 г. / редкол.: З.А. Харитончик (отв. ред.) [и др.]. Минск: МГАУ, 2012. С. 183-184.

[2] Кавров Н.И. Факультативные элементы фразеологического значения диалектных ФЕ / Н.И. Аавров / / Актуальные проблемы русской фразеологии. А., 1983. С. 108-112. 